D. Holmgren, A. Pflitsch, K. Rancourt, and J. Ringeis. Talus-and-gorge ice caves in the northeastern United States past to present-A microclimatological study. Journal of Cave and Karst Studies, v. 79, no. 3, p. 179-188. DOI: 10.4311/2014IC0125

\title{
TALUS-AND-GORGE ICE CAVES IN THE NORTHEASTERN UNITED STATES PAST TO PRESENT-A MICROCLIMATOLOGICAL STUDY
}

\author{
David Holmgren ${ }^{1, C}$, Andreas Pflitsch ${ }^{1}$, Kenneth Rancourt $^{2}$, and Julia Ringeis ${ }^{1}$
}

\begin{abstract}
The focus of this article is both a region and a type of cave not typically associated with ice caves. Nevertheless, both the region and the type play an important role in American ice-cave research. Talus-and-gorge ice caves in the northeastern United States can be used as climate indicators for a whole region; and therefore, they are the target of this young field of research. Ice caves, in general, are sensitive climatopes that can serve as excellent indicators for short and long term changes in the climate of a region, principally because of shifts between phases of increasing ice growth and melting during a year and over time. This research started with an investigation of known talus-and-gorge ice caves, followed by environmental monitoring of selected caves with perennial ice that were equipped with temperature sensors recorded over four years. This is one of the world's longest high-resolution climatologic monitoring record of such caves. In addition, the height of the ice was surveyed annually at a time when ice would most likely be at its minimum, the start of November. This allowed for investigation of the annual changes and the influence of the temperature over the previous year. Some predictions for the future of the ice caves and the whole region could be deduced from the data. At the moment, there is no sign of either a renewed increase in the number of talus-and-gorge ice caves or an increase in ice accumulation within the existing ones.
\end{abstract}

\section{Introduction}

The northeastern United States is not well known for large ice caves, and only a few know that it is the region with the most fossil and recent ice caves in the United States. The most common type of ice cave in this area is the talusand-gorge ice caves (TGICs), which are caves with perennial ice formed within scree accumulations of huge boulders $(>1 \mathrm{~m})$ and located in talus at the bottom of steep cliffs or in narrow gorges. After completing a literature search and initial reconnaissance visits in 2008, it became clear that the TGICs of New England are at the risk of thawing. To better understand the melting of the ice, a monitoring network of climatic measurements and ice volume observations was established. During this investigation, maps were created that made it possible to draw conclusions on the historical development of ice in these unique settings from 1818 to the present. The scree accumulations were divided into three basic categories: those containing perennial ice, those containing seasonal ice, and those containing no ice (Holmgren et al., in press). The ice caves are in an area without permafrost. The closest isolated patches of permafrost below 1800 $\mathrm{m}$ asl are approximately $900 \mathrm{~km}$ north of the study sites (Brown et al., 2002). Only one spot of mountain permafrost is merely known from Mt. Washington (1909 m) in the Appalachian Mountains (Walegur and Nelson, 2003).

In the year 2007, initial research began on a scree-accumulation site in the White Mountains of New Hampshire. After the first year, a systematic and continuous record of the climatic data in scree accumulations with perennial ice was launched to investigate the microclimate of these special climatopes. Annual measurements of the ice volume during the likely ice minimum are contributing additional information on the climate of these ice caves.

The climatic features of TGICs are presented in the course of this article. The climate inside scree accumulations in the northeast of the U.S. is explained by assessing annual conditions and variations and by taking special short-term meteorological incidents, such as the influence of hurricanes on the climate of a talus ice cave, into consideration. Finally the factors favoring and discouraging ice accumulation in TGICs are summarized.

\section{Background}

A review of the literature shows that the northern Appalachians and the northeastern U.S. from New Jersey to Maine and from Pennsylvania to Massachusetts can be described as the region with the highest density of ice caves in the U.S. (Fig. 1a), especially the area in the Appalachian Mountains. Ice caves can be divided into natural and anthropogenic ice caves. The natural caves are solution ice caves, fissure-and-sink ice caves, talus-and-gorge ice caves, lava tube ice caves, and glacier caves. Ice forming wells and mine ice caves are anthropogenic caves in which ice has built up (Holmgren et al., 2017) Due to the lack of volcanism and glaciers in the area, lava tube ice caves and glacier caves are not present in this part of the U.S. (Halliday, 1954). All other ice cave types can be found in this area: solution ice caves, ice forming wells, fissure-and-sink ice caves, mine ice caves, and talus-and-gorge ice caves (Halliday, 1954; Holmgren et al., 2017).

\footnotetext{
1Department of Geography, Ruhr-University Bochum, Universitaetsstr. 150, 44801 Bochum, GERMANY

${ }^{2}$ Mount Washington Observatory, 2779 White Mountain Hwy, North Conway, NH 03860, USA

cCorresponding Author: david.holmgren@rub.de
} 


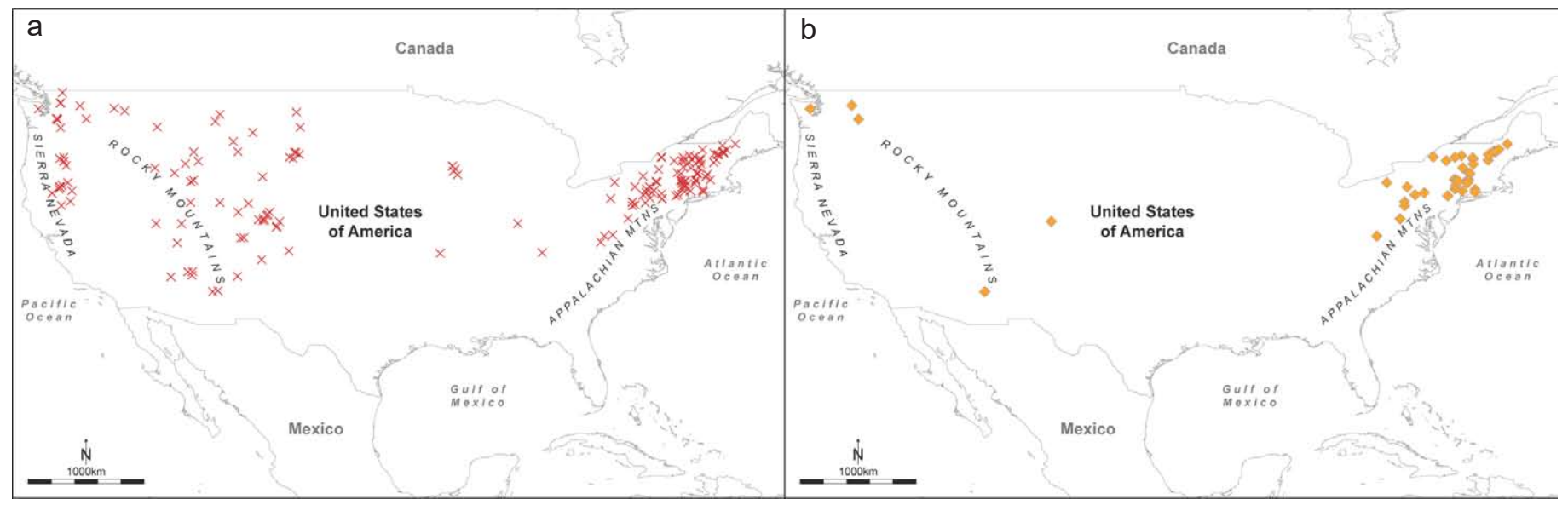

Figure 1. a: Distribution of ice caves in the United States. b: distribution of talus-and-gorge type ice caves in the United States (Holmgran and Pflitsch,in press).

The earliest references to subterranean ice in the U.S. refer to our study area, which extends from New Jersey to Maine. In 1818, Dewey visited the Snow Hole in the state of New York at the border of Vermont and Massachusetts. It contains accumulated snow masses until the late summer or even the early fall (Dearborn and Ives, 1822; Dewey, 1819). The publication of Dewey's research generated early interest in this phenomenon. This interest was at first mainly based on practical rather than scientific reasons, as the ice deposits could be used for extending the storage of food. Edwin Swift Balch was one of the first to investigate the phenomenon of ice caves for purely scientific purposes. He visited numerous ice caves and reported all his observations in various articles and a book (Balch, 1897; Balch, 1899; Balch, 1900).

\section{Talus-and-Gorge Ice Caves}

Boulders, often up to $5 \mathrm{~m}$ in diameter, deposited by weathering processes can sometimes form man size caves. Depending on the local climate and topographic relief, these caves can contain seasonal or perennial ice, especially if they are covered by vegetation or soil. The climates inside such scree accumulations are highly diverse and are discussed in this article with the aid of two locations inside a scree accumulation at the Cannon Cliff in New Hampshire. The size of a talus-and-gorge ice cave is strongly dependent upon the size of the boulders: In general, the larger the debris, the larger the air volumes among the boulders. One characteristic of these ice caves is that they are located at relatively low elevations for ice caves, as most of them can be found between 600 and $700 \mathrm{~m}$ above mean sea level. This is especially notable because the surrounding peaks of the Appalachians, like the highest point in New England, Mt. Washington in New Hampshire at 1917 m, are free from snow and ice from May to September (Holmgren and Pflitsch, 2011a; Holmgren and Pflitsch, 2011b).

The most frequent mentions in the literature to this type of cave are to be found in the northeastern U.S. (Fig. 1b; Holmgren and Pflitsch, 2012). There are also references to TGICs on the west coast of the U.S., in Washington (Halliday, 1954).

\section{Development of Talus-and-Gorge Ice Caves in New England}

An analysis of historical reference to talus-and-gorge ice caves throughout the literature, together with our physical inspections, not only resulted in the development of a map of TGICs in New England, but also made it possible to deduce a rationale for their locations. Figure 2 shows the location of TGICs in the northeastern U.S. from the earliest references up to the present day, as well as the location of the monitoring network for our current talus-and-gorge ice cave research. References to the first nine of the caves were published during the years 1818-1849 (Fig. 2a). For instance, the first talus caves with ice were described by Dewey (1819), Dearborn and Ives (1822), and Lathrop (1844). From 1850-1899 and from 1900-1949 (Fig. 2b,c) fifteen further TGICs were reported for the first time. In the 64 years since 1950, only three more ice caves of this type were described from the northeast (Fig. 2d; Holmgren and Pflitsch, 2012).

Mentions in the literature allow conclusions to be made about ice deposits only near the time the respective authors visited the sites. Therefore, an inspection of described locations since 1818 was started, and 16 of 39 TGICs were investigated in the last few years. The first results show an apparent decline of this subalpine, cold-air talus shrubland ecosystem, as five of the visited caves showed no signs of ice during the time of our visits (Fig. 2e). Indigenous plants appropriate to elevation have reconquered these niches. Alpine flora that are normally found in the immediate surroundings of TGICs and that can be used as an indicator for these types of ice caves, were completely suppressed. Examples of alpine flora in TGICs, as can currently be found in the Randolph Hill Ice Gulch in New Hampshire, are the alpine 


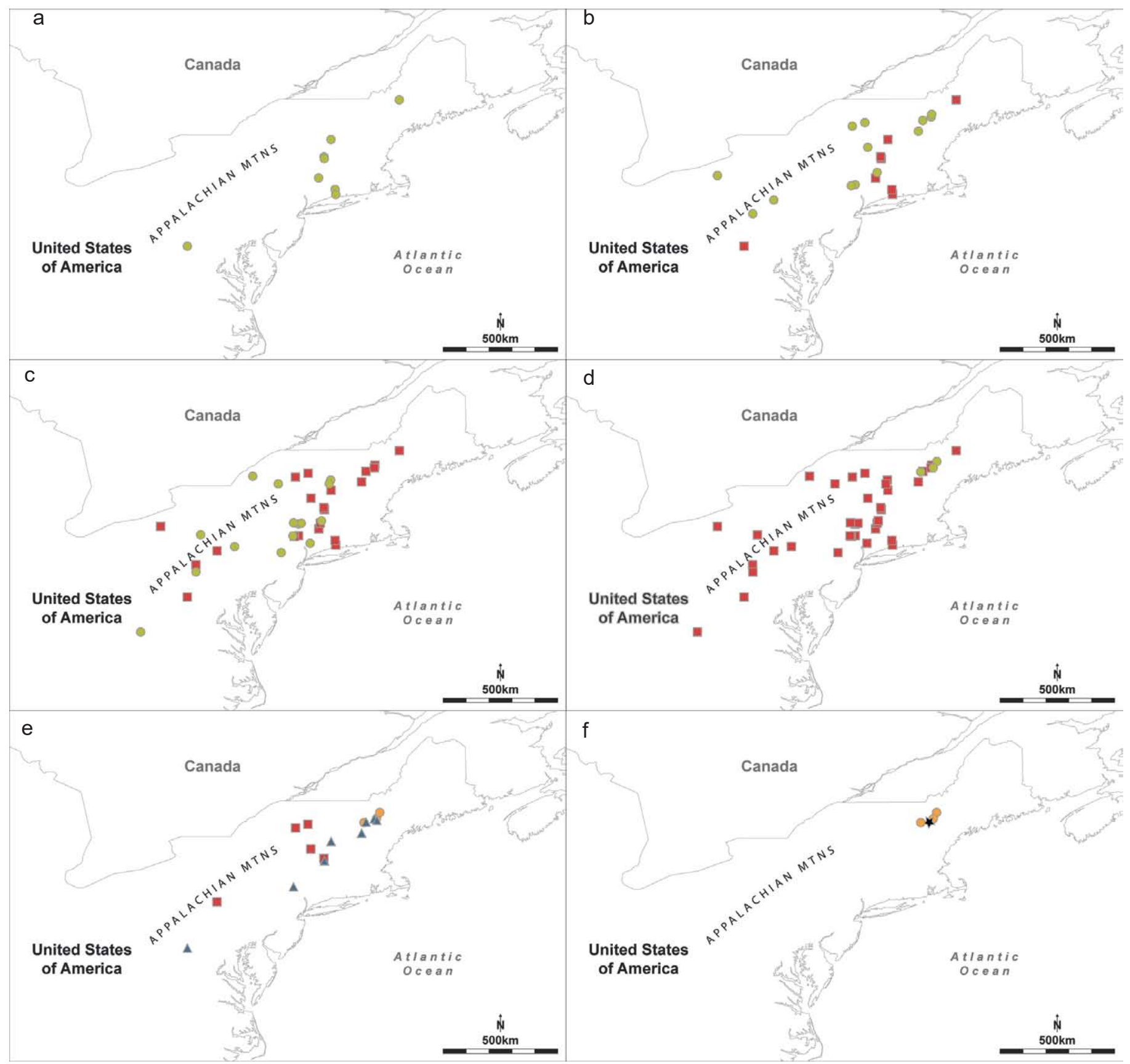

Figure 2. a-d: Locations of talus-and-gorge ice caves in the northeastern United States first described in the literature (green dots) during the periods a. 1818-1849, b: 1850-1899, c: 1900-1949, d: Since 1950. Red squares are locations of caves described in the previous periods. e: Current status of 16 historically described sites revisited for this study. Blue triangles are sites with seasonal ice; orange circles are sites with perennial ice. No ice was seen in the sites with red squares. f: The three gorge-and-talus ice caves monitored. The star is the reference weather station at Mt. Washington.

bilberry Vaccinium uliginosum and the Labrador tea Ledum groenlandicum (New Hampshire Natural Heritage Bureau, 2009). Figure $2 e$ shows the current situation, where seasonal ice deposits lasting until mid-summer were found in eight of the examined caves and only three of the caves still contain perennial ice today. The caves that still have perennial ice are in the monitoring network (Fig. 2f).

\section{Gorge Ice Caves}

Gorge ice caves can be found in narrow cuts in valleys or ravines with scree accumulations. In the scree-accumulation zone, debris falls to the bottom of the ravine due to various weathering processes. The ice deposits of these ice caves can be found within the debris (Fig. 3a). Because of continuing frost action, the majority of new boulders fall into the gorge during the frequent freeze/thaw cycles. The sidewalls of a gorge are very steep and quite often reach 80 or $90 \mathrm{~m}$ in the study area (Fig. 4a). With the width of the gorge not exceeding 30 to $35 \mathrm{~m}$, the walls significantly reduce the 
incoming solar radiation. Usually the scree accumulation is only heated by direct sunlight at noon.

Research on TGICs is common in Europe (Juliussen and Humlum, 2008; Růžička et al., 2012), especially in the European Alps (Morard et al., 2008; Zacharda et al., 2007), and also in Asia (Byun et al., 2011; Gorbunov et al., 2004). Different climatological processes based on the topography, for example the chimney effect, have been detected in scree accumulations (e.g., Sawada et al., 2003). But only a few studies concentrate on long-term investigations over several years (e.g., Byun et al., 2011, and Delaloye and Lambiel, 2005). While we concentrate on the ice development in small caves among the TGICs, Byun et al. investigated some anomalous winter warming and summer cooling in the Miryang Eoreumgol (Ice Valley) in Korea and Delaloye and Lambiel measured the temperature of whole scree slopes at different depths up to $5.75 \mathrm{~m}$.

\section{Site Characteristics and Measurement Setup}

The scree accumulations with perennial ice are located in the northeastern states of the Appalachians, New Hampshire and Maine. The study sites (Fig. 2f) can be found in a $40-\mathrm{km}$ perimeter around Mt. Washington $\left(44^{\circ} 16^{\prime} 12^{\prime \prime} \mathrm{N} /\right.$ $\left.71^{\circ} 18^{\prime} 11^{\prime \prime} \mathrm{W}\right)$. The exposure of the individual locations varies from northeast at Mahoosuc Notch, to southeast at Cannon Cliff; the Ice Gulch has an exposure towards the east-southeast. The subcategory of gorge ice caves is represented by the Ice Gulch and the Mahoosuc Notch sites, while the talus of the Cannon Cliff belongs to the subcategory talus ice

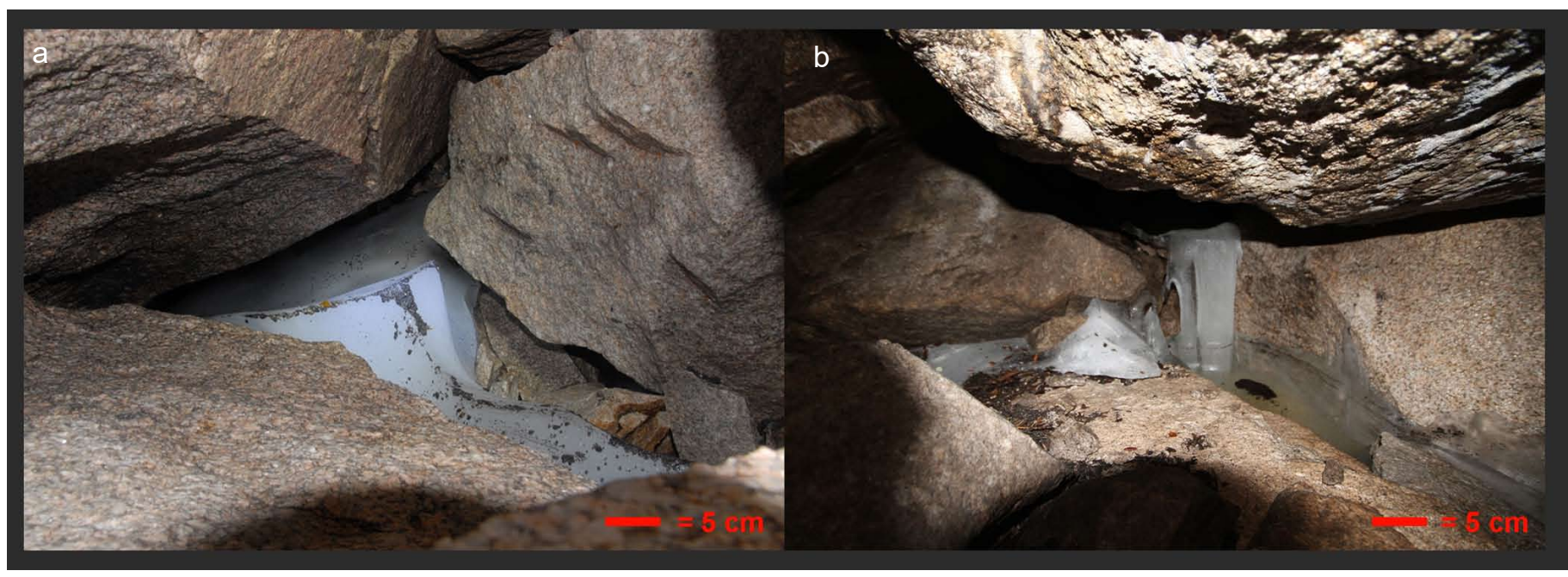

Figure 3. a: Talus with ice in Randolph Hill Ice Gulch, New Hampshire (October 2008). b: Debris with ice in the talus below Cannon Cliff, New Hampshire (June 2010).

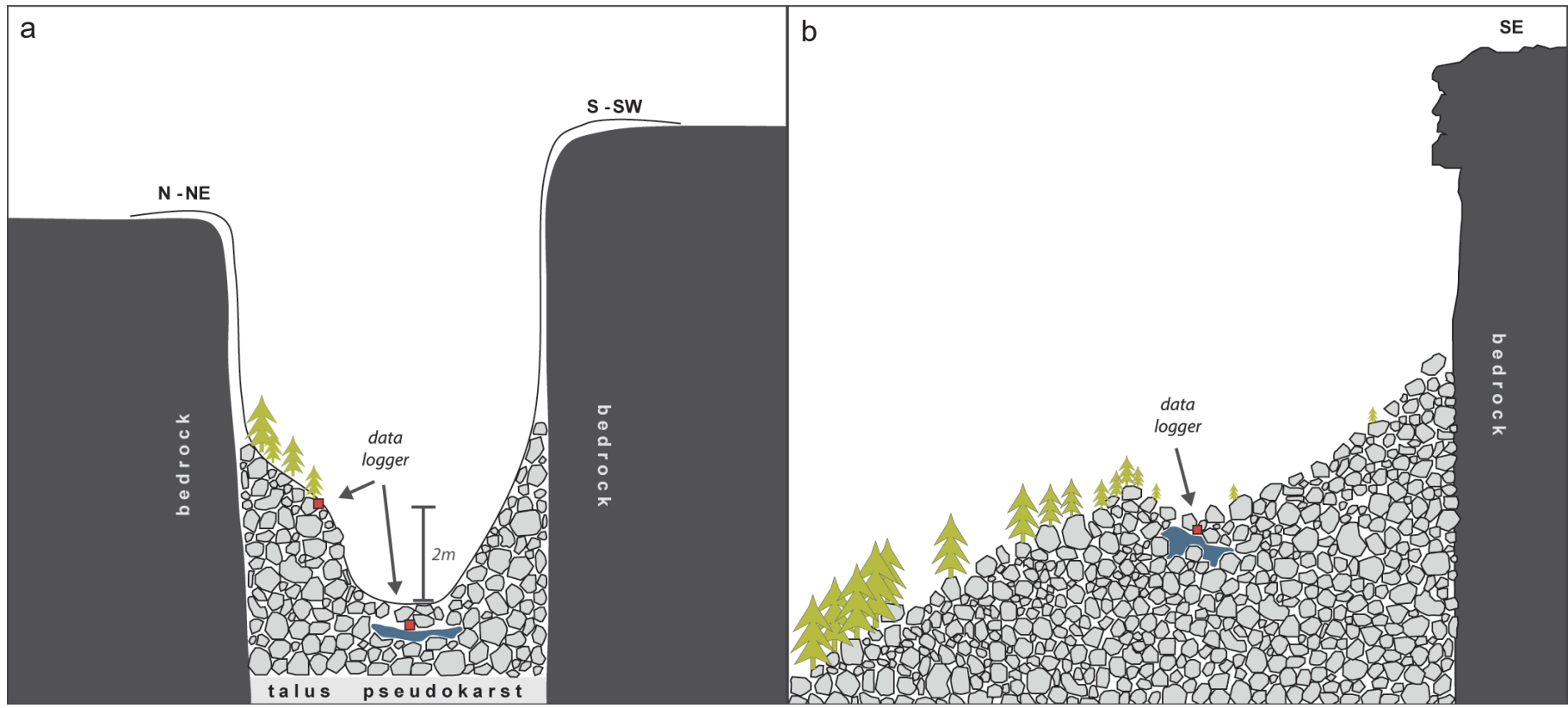

Figure 4. a: Profile of a gorge ice cave showing protective sidewalls and typical positions of instruments to record temperatures, based on Holmgren and Pflitsch (2011b). b: Schematic section of a talus ice cave showing location in scree where cold air accumulates; cliff orientation shown for Cannon Cliff. 
caves. In the case of the gorge ice caves, it has to be taken into consideration that high sidewalls of $80 \mathrm{~m}$ to $90 \mathrm{~m}$ height, not uncommon, strongly reduce the incoming solar radiation. Therefore, direct sunlight might only reach the debris at noon, and then for only a short period of time. In contrast, the scree of the talus ice caves on Cannon Cliff is exposed to incoming solar radiation during many hours of the day. The locations of the ice deposits, and thus the locations of the measurements, can be found over a narrow range of elevations, 668 to $689 \mathrm{~m}$.

The measurements started in October 2008 to generate an analysis of the micro-climate inside the Ice Gulch at 670 m elevation in New Hampshire. This gorge ice cave was equipped with high-resolution temperature sensors (resolution of $0.01^{\circ} \mathrm{C}$; accuracy of $0.1^{\circ} \mathrm{C}$ ). The air temperature sensors were placed at the vegetation boundary and within the ice cave some centimeters above various ice deposits. In October 2009, the monitoring network was extended by the addition of another gorge ice cave. The Mahoosuc Notch in Maine was similarly equipped with sensors measuring the air temperature close to the ice deposits. Finally, in July 2010 the scree accumulation at Cannon Mountain, New Hampshire, was also equipped with high-resolution temperature sensors at similar positions to the other caves. Unlike at the other sites, we also investigated two sites inside the scree accumulation of Cannon Mountain that contain both seasonal and perennial ice. Additional visits on a regular basis during the potential ice minimum and occasional visits during the potential ice maximum were made to better understand and document the development of the thickness of the ice.

The data gathered by numerous climate stations of the Mount Washington Observatory Meso-Net served as local long-term reference values. The auto road station at $701 \mathrm{~m}$ on Mount Washington has a similar elevation as the Ice Gulch and has the same exposure. This reference station delivers high resolution data on both temperature and humidity. In addition, the summit station delivers wind direction and velocity.

Since 2008, the air temperature in the Randolph Hill Ice Gulch has been recorded every 15 minutes. The four-year means in the Ice Gulch for $2008-2012$ were an air temperature of $-0.91{ }^{\circ} \mathrm{C}$ at the vegetation boundary and $-3.75{ }^{\circ} \mathrm{C}$ inside the caves close to the ice deposits 1 to $2 \mathrm{~m}$ under the surface of the debris (Fig. $4 \mathrm{a}$ ). In comparison, a reference station at a similar elevation above had a temperature mean of $+4.83^{\circ} \mathrm{C}$, while the mean air temperature of the summit of Mt. Washington (1247 $\mathrm{m}$ higher than Ice Gulch) was $-1.75^{\circ} \mathrm{C}$ during the same time period. That means the gulch ice caves have a lower mean air temperature than the highest mountain tops in the northeastern U.S. Therefore, the measurements at the Ice Gulch are comparable to areas in this region with an elevation much higher than $1500 \mathrm{~m}$ above sea level. The low temperatures in the Ice Gulch are responsible for the presence of alpine flora such as alpine bilberry and Labrador Tea. Monthly means are shown in Figure 5, which shows the air temperatures at the reference station (Mt. Washington auto road station, $701 \mathrm{~m}$ ), at Mt. Washington's summit, at the vegetation boundary at the Ice Gulch, and at an ice deposit inside Ice Gulch. The similarity between the air temperature at the Ice Gulch (670 m) and the peak of Mt. Washington (1917 m) is clearly seen. The differences in the monthly mean temperatures between the Ice Gulch and the summit station of Mt. Washington are in a range of $3.3 \mathrm{~K}$, whereas the reference station at $701 \mathrm{~m}$ on Mt. Washington is at least $2.5 \mathrm{~K}$ and up to $7.4 \mathrm{~K}$ warmer than the Ice Gulch in every month. From May to November the mean air temperatures of the region stay above the freezing point. Inside Ice Gulch, positive air temperature values can be found from May to October, but close to the ice deposits the mean air temperature only exceeds the freezing point for three months. From August to October the mean air temperature is between $0{ }^{\circ} \mathrm{C}$ and $+1.5^{\circ} \mathrm{C}$.

During a single year the temperature profile of the Ice Gulch exhibits distinct annual phases: the cooling phase, a

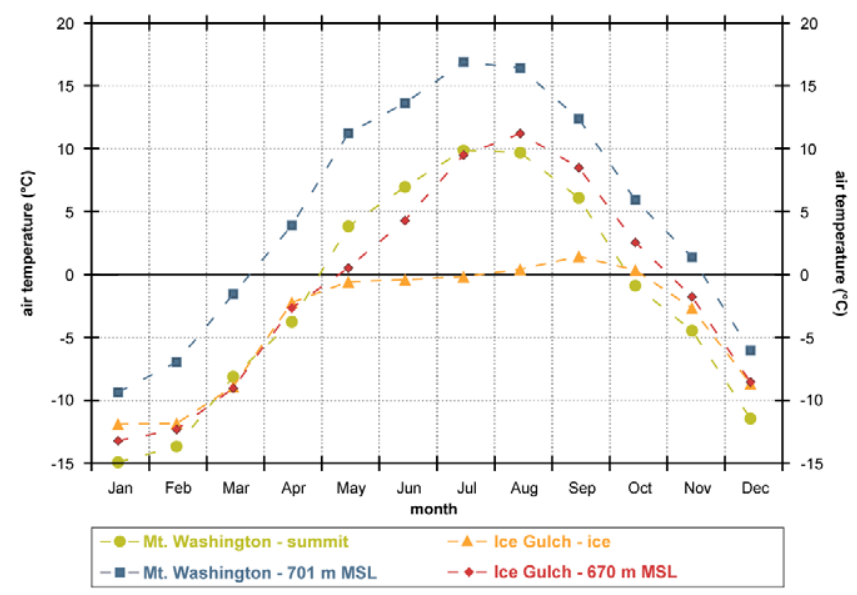

Figure 5. Monthly mean temperature records in Randolph Hill Ice Gulch, both at the top of the scree deposit (red) and at the ice (orange), compared to temperatures at a similar elevation on Mt. Washington (blue) and at its summit (green). zero-curtain phase, and the warming phase, before the cycle starts again with another cooling phase (Fig. 6). During the cooling phase, from October to the end of April, temperatures stay continuously under $0{ }^{\circ} \mathrm{C}$. This phase can be further divided into three periods. It is a characteristic of the first half of the cooling phase that the air temperature inside Ice Gulch follows the negative temperature of the surroundings without delay because the debris begins to cool down instantly. Lighter and warmer air masses are displaced by heavier and colder air during this period, the phenomenon also described by Delaloye and Lambiel (2005). In the second half of the cooling phase snowfall accumulation plays an important role. The temperatures inside the scree accumulation then have a delayed reaction to the influence of colder air as the pores in the snow blanket are closed more and more by the increasing snow depth. When the snow blanket is nearly fully closed, the debris only reacts to temperature extremes, which normally occur from the end of March to the end of April. 
Figure 6. Detailed temperature records for November 2008 through October 2009 for Randolph Hill Ice Gulch, both at the top of the scree deposit (green) and at the ice (red), compared to the temperature at a site on Mt. Washington with similar elevation.

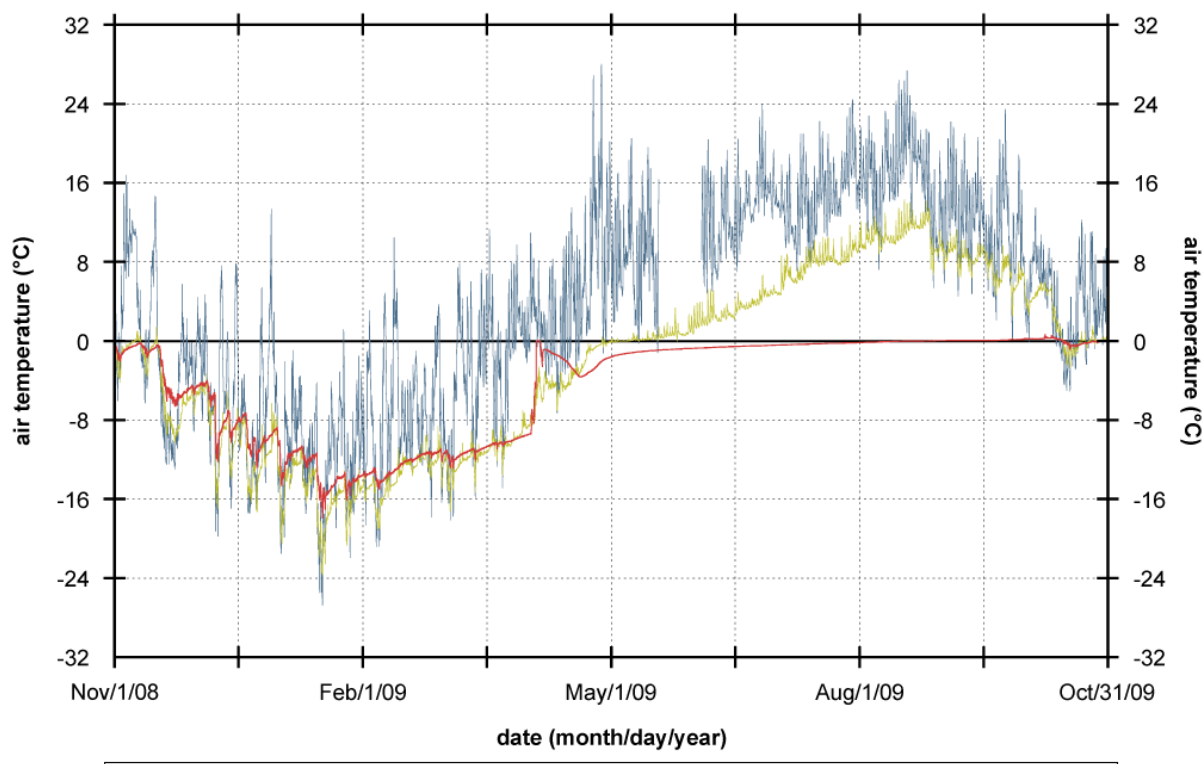

— Mt. Washington - 701 m MSL - Ice Gulch - ice

During the second phase, the zero-curtain, which typically starts in May, the air temperature slowly rises to the freezing point independent of the surrounding temperatures that already show daily means of up to $10^{\circ} \mathrm{C}$. The zero-curtain arises during the phase transition of $\mathrm{H}_{2} \mathrm{O}$. Snowmelt runs into the debris and freezes again when meeting the colder air and boulders, creating new layers of ice. During the phase transition, energy is set free (Hanson and Hoelzle, 2004).

After the passing of $0^{\circ} \mathrm{C}$, hence the end of the zero-curtain, the last phase, the warming phase, begins. The regional temperature increases from the end of May to the end of August by up to $15 \mathrm{~K}$. In the immediate area of the Ice Gulch, the temperature not uncommonly reaches 29 or $30^{\circ} \mathrm{C}$. On average, the temperature differences between the cave and the environment during the Warming Phase are approximately $14 \mathrm{~K}$. In September, the temperature drops to the freezing point and ends the annual cycle. Then a new cooling phase can begin in October.

\section{Analysis and Discussion}

The phenomena of the great temperature differences between the debris and its surrounding area during summer and the small temperature differences during winter can be explained by using the theory of Rayleigh-Bénard convection, or in this special case, by using Horton-Rogers-Lapwood convection (Cheng et al., 2007). The Rayleigh-Bénard convection theory requires a liquid that is consistently heated. The warmer liquid will ascend because of decreasing density and a circulation will begin. By exchanging the liquid for a porous rock surface, such as a scree accumulation and the air pockets within it, you get the Horton-Rogers-Lapwood convection that better describes the wintery situation in scree accumulations. Colder and heavier air masses enter the debris because of density differences, suppressing the warmer air and starting a circulation (Fig. 7a). This process occurs in New England every fall, cooling down the scree accumulation. Due to the harsh conditions in winter and spring in the remote locations, we don't have visual observations of the snow cover and possible ventilation effects like melt holes in the upper part of slopes in the snow cover as described by Delaloye and Lambiel (2005).

The expected circulation inside the debris decreases during winter (Fig. $7 \mathrm{~b}$ ) due to the lower temperature differences until it reaches an equilibrium (Fig. 7c) in spring, when the outer air temperature exceeds the air temperature inside the debris. A likely snow blanket further isolates the air in the cave. The warming during the following summer is limited. This warming occurs by heat conduction and by warming in a mixed layer close to the surface (Fig. 7d). This layer deepens in the course of the summer and reaches its maximum in fall, when its influence on the debris is the strongest. The profile of the circulation inside the debris in the course of the year is the reason for the relatively high differences inside Ice Gulch between the air temperature at the vegetation boundary and in the debris, especially in summer (Bardan and Mojtabi, 2000; Cheng et al., 2007; Nield and Bejan, 1992).

By comparing the temperature profiles of the four consecutive years (Fig. 8a) of available data, significant differences catch the eye. These differences are mainly shaped by the climate of the region. Annual differences in summer and winter dominate the temperatures inside Ice Gulch. The first year, 2008-2009, was the coldest year of the measurement period. This year had a mean winter temperature (November-April) of $-9.62{ }^{\circ} \mathrm{C}$ and a mean summer temperature (May-October) of $+5.22^{\circ} \mathrm{C}$. This was a combination of the coldest winter and the mildest summer, and 


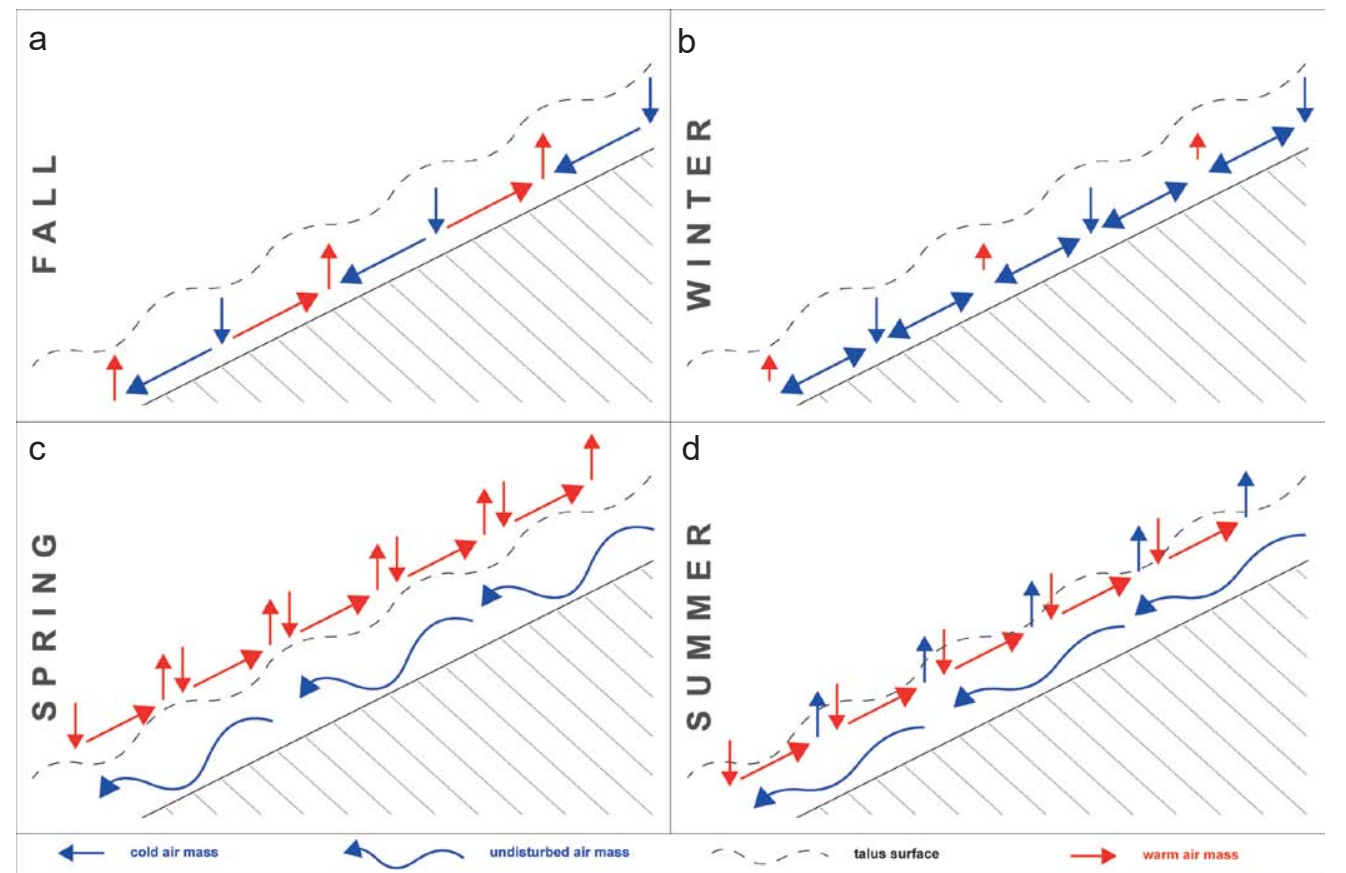

Figure 7. Schematic depictions of the air circulation in talus. In the fall, cold air sinks into the talus and displaces warmer air. In the winter, this process has been substantially completed. In the spring, the denser cold air, perhaps protected by snow cover, remains stagnant in the caves. In summer, much cold air remains, although there is some replacement by warm air in the upper parts of the talus deposit.

therefore, it was by far the coldest year, with an annual average of $-2.20^{\circ} \mathrm{C}$ (see Table 1). In contrast, the warmest year (2011-2012) had a positive mean air temperature of $0.14{ }^{\circ} \mathrm{C}$ (winter period $-6.60{ }^{\circ} \mathrm{C}$; summer period $+6.88^{\circ} \mathrm{C}$ ), leading to a decrease of the ice thickness.

The different temperature regimes of each year are represented in the data on the ice's thickness. The observations of the thickness during the likely ice minimum resulted in irregular data, but still give the appearance of a negative year-to-year trend (Fig. 8b). Nevertheless, one fact could be ascertained clearly from the correlation of the data on the thickness of the ice deposits and the air temperature inside Ice Gulch: the air temperature is the driving force for the ice development. The data show that mean annual air temperatures lower than $-1.25^{\circ} \mathrm{C}$ lead to an increase in the ice deposits, while means above $-1.25^{\circ} \mathrm{C}$ lead to a decrease in ice thickness at similar humidity conditions. This relation is expressed by the formula $y=-0.639 x^{3}-0.413 x^{2}-10.335 x-13.543$, where $x$ is the mean annual temperature and $y$ is the excess or deficit in minimum ice thickness in $\mathrm{cm}$ compared to $-1.25^{\circ} \mathrm{C}$. The results of this correlation have to be verified in subsequent years and supported by further data. Possibly the point of stagnating ice levels is off by some hundredths of a degree, but the calculation based on the last years looks plausible.

\section{Talus Ice Caves}

Scree accumulations that are protected only from one side by a cliff while the other sides are exposed to wind and sun can contain ice deposits and are named talus ice caves (Fig. 4b). The orientation of the exposed side is of great importance. The Talus Ice Caves at Cannon Cliff are exposed to the southeast; they receive the highest incoming solar radiation during the morning, and seasonal, as well as perennial, ice can be found in some of the caves. The perennial ice has a thickness of several meters, while the seasonal ice deposits can exhibit a thickness of up to one meter during

Table 1. Monthly mean and annual average air temperatures of Ice Gulch.

\begin{tabular}{lccccc}
\hline \multicolumn{1}{c}{ Month $^{\mathbf{a}}$} & $\mathbf{2 0 0 8 / 2 0 0 9}$ & $\mathbf{2 0 0 9 / 2 0 1 0}$ & $\mathbf{2 0 1 0 / 2 0 1 1}$ & $\mathbf{2 0 1 1 / 2 0 1 2}$ & Mean \\
\hline November & -3.56 & -0.43 & -1.98 & -1.06 & -1.76 \\
December & -10.08 & -9.08 & -8.99 & -6.01 & -8.54 \\
January & -15.58 & -11.65 & -13.16 & -12.40 & -13.20 \\
February & -13.49 & -10.93 & -14.05 & -10.69 & -12.29 \\
March & -11.34 & -6.62 & -10.44 & -7.69 & -9.02 \\
April & -3.64 & -0.73 & -4.47 & -1.73 & -2.64 \\
May & 0.39 & 0.5 & 0.15 & 1.05 & 0.52 \\
June & 3.24 & 4.45 & 3.53 & 5.99 & 4.3 \\
July & 7.7 & 10.06 & 9.51 & 10.7 & 9.49 \\
August & 10.73 & 10.95 & 11.2 & 12.02 & 11.23 \\
September & 7.68 & 8.98 & 9.09 & 8.19 & 8.49 \\
October & 1.55 & 2.67 & 2.64 & 3.35 & 2.56 \\
\hline Annual Mean & -2.20 & -0.15 & -1.41 & 0.14 & -0.91 \\
\hline a Measurements & & & & &
\end{tabular}


the annual maximum (Fig. 3b). The curves in Figure $8 \mathrm{c}$ show the various temperature profiles of the talus locations with perennial or seasonal ice deposits in the course of a year. Differences develop especially during the extremes of the year. In winter, the air temperature at the locations with seasonal ice is 2 to $3 \mathrm{~K}$ higher than at the locations with perennial ice. Furthermore the air at these locations is heated up faster in summer and reaches temperatures that are 5 to 6 $\mathrm{K}$ higher than at the locations with perennial ice.

The local shape of the scree accumulation is the reason for the different temperature profiles. Only in scree accumulations with protection for the cold is it possible for ice to build up in this region and elevation. This is found in all three study areas in the monitoring network. At the talus of Cannon Cliff this barrier is a protalus rampart (Whalley and Azizi, 2003) that is especially distinct at the location with perennial ice deposits (Fig. 4b). This is the main reason for the high temperature differences in winter and particularly in summer. Heavier cold air accumulating in a synclinal shape in the scree accumulation forms a protected pool of cold air. Another contributing factor is the biological growth at the rear of the barrier. Mosses, lichens, and other soil material protect the cold air from runoff. This system can only be disturbed by events with very strong winds, such as hurricanes.

\section{The Influence of Hurricane Irene (August 2011) on the Cannon Cliff}

Because one of their sides is especially exposed to the weather, talus ice caves like the ones on Cannon Cliff are more strongly influenced by weather events than gorge ice caves. At the end of August 2011, the impact of Hurricane Irene had a strong influence not only on the climate of the east coast, but also on the microclimate of the talus ice caves of New England. The effects of this storm can be seen in the temperature profile inside the scree accumulation of Cannon Cliff (Fig. 9). This figure shows an unusual increase of the air temperature near the ice deposits. Daily temperature fluctuations normally don't exceed 0.3 to $0.4 \mathrm{~K}$. Two factors were responsible for the extreme temperature increase on August 28-29, 2011. There were winds up to $132 \mathrm{~km} \mathrm{~h}^{-1}$ blowing directly at the debris (orange dots), pushing warm air into the debris. Twelve hours after Irene first hit this region, the rear of the hurricane tore across the country. The wind direction reversed by $180^{\circ}$, and even with a wind velocity that was $31 \mathrm{~km} \mathrm{~h}^{-1}$ faster than the initial phase, the microclimate of the now leeward scree accumulation wasn't influenced at all, showing that the combination of the wind direction and speed was essential for the temperature jump.

Only one thing can protect the microclimate from such strong influences-a seasonal, deep snow blanket that lasts until the late spring or early summer protects the scree accumulation from warming and has a positive influence on the cave ice. The presence of an isolating snow blanket during spring and early summer prevents strong winds such as those from Hurricane Irene from pressing warmer air into the debris that would add to the warming of the cave air and the melting of the ice deposits. By the beginning of the hurricane season, the snow blanket doesn't exist, so such extreme events can lead to increased ablation rates.

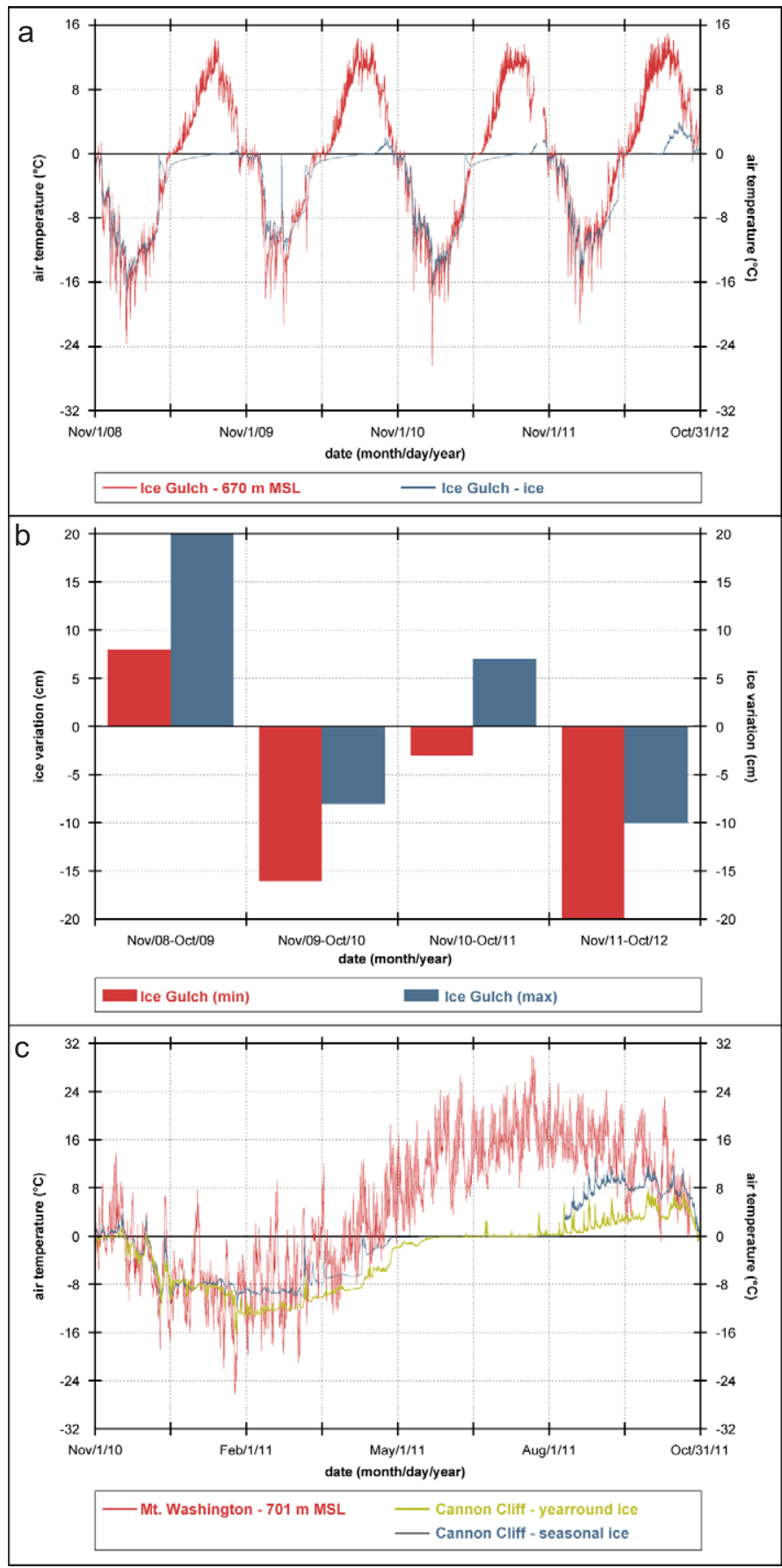

Figure 8. a: Four-year record of the temperature at Randolph Hill Ice Gulch, both on the surface of the scree (red) and at the ice (blue). b: The differences in thickness of the ice deposit inside Randolph Hill Ice Gulch from the previous year, based on visits when the deposit was expected to be at its minimum and maximum during the same year-long periods as in part a. c: Detailed temperature records at the Cannon Cliff talus ice cave deposits of seasonal (blue) and perennial (green) ice, compared to the air at a weather station with similar elevation on Mt. Washington. 
Figure 9. Detailed temperature record inside the scree accumulation at Cannon Cliff (green) during the passage of Hurricane Irene in August 2011, compared to temperature record (blue) at a site with similar elevation on Mt. Washington as well as the record of wind velocity (red) and direction (orange) at the summit of the mountain (both on right scale). The high winds affected the temperature in the scree only when the wind direction was favorable.

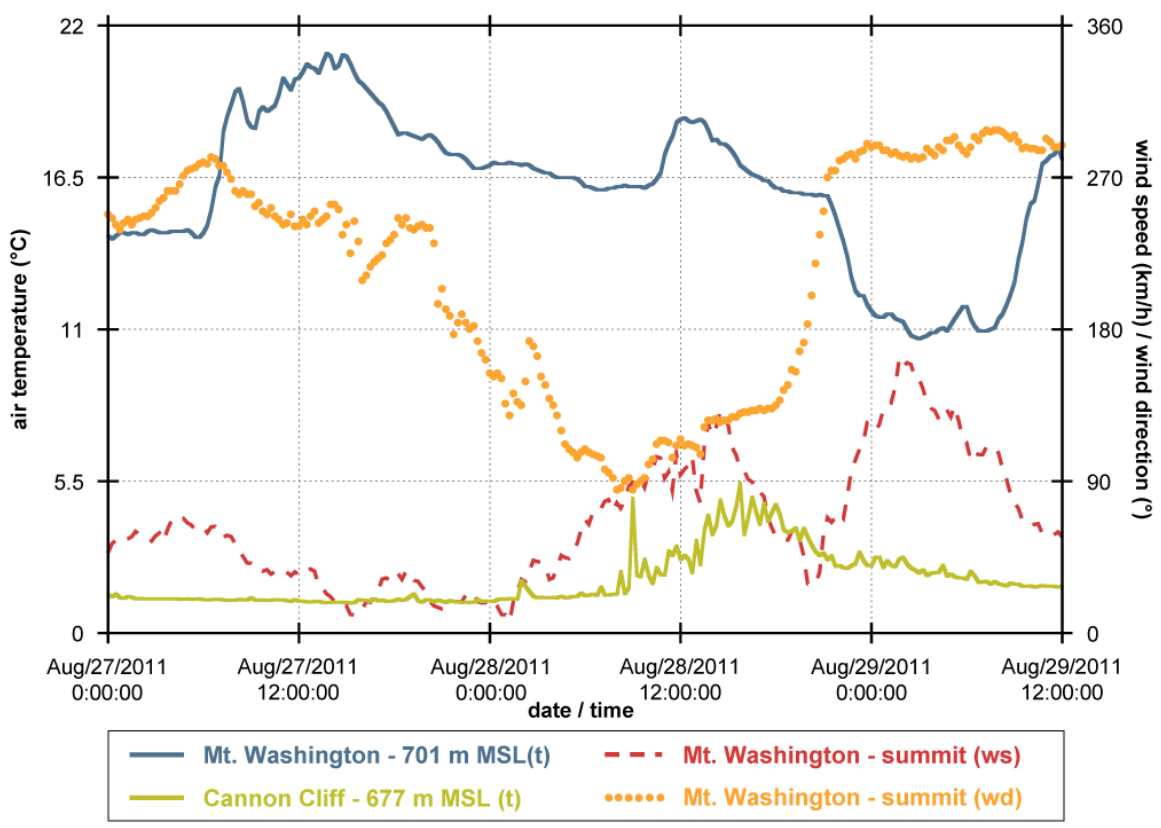

\section{Conclusions}

After visits to 16 talus-and-gorge ice cave locations in New England, the preliminary conclusion can be drawn that the number of TGIC is decreasing. Of the visited ice caves that researchers had noted since $1818,31 \%$ are now ice free. Just $19 \%$ of the surveyed locations show perennial ice deposits. These results support the assumption that we had a maximum of TGICs at the end of the Little Ice Age in the fifteenth through nineteenth centuries. The large number of first descriptions in the literature matches perfectly with the end of this period.

The last place with permafrost other than in a cave east of the Rocky Mountains is the summit area of Mount Washington, New Hampshire (Osterkamp and Jorgenson, 2009). TGIC, or ice caves in general, can be considered as ground ice occurrences. That means that these three TGIC and ice caves of other types, if they have perennial ice, are the last lowland permafrost spots east of the Rocky Mountains in the U.S. These cave ice deposits clearly represent a peculiar type of ground ice, both in terms of volume, no more than $3 \mathrm{~m}^{3}$ per deposit and $14 \mathrm{~m}^{3}$ per ice cave, and by being in a climate not usually associated with permafrost. French (2007), Kern and Persoiu (2013), and Luetscher et al. (2005) have previously mentioned the important role of cave ice in terms of permafrost. Cave ice, enclosed in rock not soil, could offer new opportunities for ice cave and permafrost research if incorporated in the existing category of sporadic and mountain permafrost or made a new permafrost category.

The volumes of the ice deposits vary as a function of the climatic conditions of a year. An obvious long-term trend could not be deduced from the first years of this study. Therefore, no clear statement can be made concerning melting of the ice deposits inside the scree accumulations or risk to the current climatope in general. However, a plausible statement about climatic factors affecting ice deposits at lower elevations could be formed and is summarized in Table 2 .

Cold temperatures in early fall cool down the debris relatively early and foster the buildup of ice deposits, provided that early snow falls do not create a snow blanket that seals the openings. Low minimum temperatures and high wind velocities all contribute to ideal winter conditions. A protective snow blanket in late spring strongly inhibits the warming temperatures from influencing the deeper parts of the scree accumulation. Meltwater entering the debris at this point is of fundamental importance for the buildup of the ice deposits. A summer with low precipitation and low wind velocities

Table 2. Factors in favor and disfavor of the build-up of ice deposits in talus accumulations.

\begin{tabular}{lll}
\hline Season & \multicolumn{1}{c}{ Positive Influence } & \multicolumn{1}{c}{ Negative Influence } \\
\hline Fall & Early freezing temperatures & $\begin{array}{l}\text { Early snow cover } \\
\text { Winter }\end{array}$ \\
& $\begin{array}{l}\text { Cold and windy conditions } \\
\text { Light snowfall }\end{array}$ & $\begin{array}{l}\text { High temperatures } \\
\text { Spring }\end{array}$ \\
& $\begin{array}{l}\text { Closing snow cover } \\
\text { High humidity }\end{array}$ & $\begin{array}{l}\text { Deep snow cover } \\
\text { High wind speeds }\end{array}$ \\
& & High amounts of precipitation \\
Summer & $\begin{array}{l}\text { Dry conditions / Less precipitation } \\
\text { Low wind speeds }\end{array}$ & $\begin{array}{l}\text { Early summer temperatures } \\
\text { High amounts of precipitation } \\
\end{array}$ \\
\hline
\end{tabular}
causes the least melting of the ice and warming of the debris.

High temperatures throughout the year combined with high wind velocities have an extraordinarily negative impact on the cave ice. In addition, a snow blanket that is closed too soon in late fall or early winter prevents the invasion of cold air into the scree accumulation. Some of these factors affect gorge ice caves and talus ice caves to different extents. Gorge ice caves are nearly solely influenced by the air temperature, whereas the microclimate of talus ice caves also is depen- 
dent on strong winds and other climatic or topographic features.

The results of this study have shown that the development of perennial ice deposits in caves depends not just the climate of a region. Topography influencing micro climates also play an important role. Landforms with cold air trapping functions are essential for the development and protection of cold air pools inside scree accumulations. In the areas near these pools, ice can be found.

\section{References}

Balch, E.S., 1897, Ice caves and the causes of subterranean ice: Journal of Franklin Institute, v. 143, no. 3, p. 161-178. doi:10.1016/S00160032(97)90146-0.

Balch, E.S., 1899, Subterranean ice deposits in America: Journal of Franklin Institute, v. 147, no. 4, p. 286-297. doi:10.1016/S00160032(99)90250-8.

Balch, E.S., 1900, Glacières or Freezing Caverns: Philadelphia, Allen, Lane \& Scott, 337 p. Bardan, G., and Mojtabi, A., 2000, On the Horton-Rogers-Lapwood convective instability with vertical vibration: Onset of convection: Physics of Fluids, v. 12, no. 11, p. $2723-2731$. doi:10.1063/1.1313551.

Brown, J., Ferrieans, O., Heginbottom, J.A., and Melnikov, E., 2002, Circum-Arctic Map of Permafrost and Ground-Ice Conditions, Version 2: Boulder, Colorado, National Snow and Ice Data Center digital media, https://nsidc.org/data/ggd318 [accessed March 03, 2014].

Byun Hi-Ryong, Tanaka, H.L., Choi Pom-yong, and Kim Do-Woo, 2011, Seasonal reversal at Miryang Eoreumgol (Ice Valley), Korea: Observation and monitoring: Theoretical and Applied Climatology, v. 106, no. 3-4, p. 403-415. doi:10.1007/s00704-011-0429-5.

Cheng Guodong, Lai Yuanming, Sun Zhizhong, and Jiang Fan, 2007, The 'thermal semi-conductor' effect of crushed rocks: Permafrost and Periglacial Processes, v. 18, no. 2, p. 151-160. doi:10.1002/ppp.575.

Dearborn, H.A.S., and Ives, T., 1822, Natural ice houses near Williamstown, Mass Lat. $42^{\circ}$ 38' N. Lon. $73^{\circ} 15^{\prime}$ W from London: American Journal of Science and Arts, v. 4, p. 331-332.

Delaloye, R., and Lambiel, C., 2005, Evidences of winter ascending air circulation throughout talus slopes and rock glaciers situated in the lower belt of alpine discontinuous permafrost (Swiss Alps): Norsk Geografisk Tidsskrift, v. 59, p. 194-203. doi:10.1080/00291950510020673.

Dewey, C., 1819, Sketch of the mineralogy and geology of the vicinity of Williams' College, Williamstown, Mass: American Journal of Science and Arts, v. 1, p. 337-346.

French, H.M., 2007, The Periglacial Environment, third edition: Chichester, UK, John Wiley \& Sons Ltd., 480 p.

Gorbunov, A.P., Marchenko, S.S., and Seversky, E.V., 2004, The thermal environment of blocky materials in the mountains of central Asia: Permafrost and Periglacial Processes, v. 15, p. 95-98. doi:10.1002/ppp.478.

Halliday, W.R., 1954, Ice caves of the United States: The American Caver - Bulletin of the National Speleological Society, v. 16, p. 3-28.

Hanson, S., and Hoelzle, M., 2004, The thermal regime of the active layer at the Murtèl Rock Glacier based in data from 2002: Permafrost and Periglacial Processes, v. 15, no. 3, p. 273-282. doi:10.1002/ppp.499.

Holmgren, D., and Pflitsch, A., 2011a, Microclimatological survey of the Ice Gulch in the White Mountains, New Hampshire, USA, 11th International Symposium on Pseudokarst, Saupsdorf, Germany, Abstract with Programs, p. 72-73.

Holmgren, D., and Pflitsch, A., 2011b, The Ice Gulch-Perennial Ice in the White Mountains: Windswept, The Quarterly Bulletin of Mount Washington Observatory, v. 52, no. 4, p. 20-23.

Holmgren, D., and Pflitsch, A., 2012, Talus \& Gorge Glacier past to present-A historical and microclimatological research in the northeastern United States, 5th International Workshop on Ice Cave, Abstracts, p. 29.

Holmgren, D., Pflitsch, A., Ringeis, J., and Meyer, C., 2017, Ice cave research of the United States. Journal of Cave and Karst Studies, v. 79, no. 3, p. 146-152. doi:10.4311/2014IC0116.

Juliussen, H., and Humlum, O., 2008, Thermal regime of openwork block fields on the mountains Elgåhogna and Sølen, central-eastern Norway: Permafrost and Periglacial Processes, v. 19, no. 1, p. 1-18. doi:10.1002/ppp.607.

Kern, Z., and Perşoiu, A., 2013, Cave ice-the imminent loss of untapped mid-latittude cryospheric palaeoenvironmental archives: Quaternary Science Reviews, v. 67, p. 1-7. doi:10.1016/j.quascirev.2013.01.008.

Lathrop, S.P., 1844, Notice of an Ice Mountain in Wallingford, Rutland County, Vermont: American Journal of Science and Arts, v. 46, p. 331-332.

Luetscher, M., Jeannin, P-Y., and Haeberli, W., 2005, Ice caves as an indicator of winter climate evolution: A case study from the Jura Mountains: The Holocene, v. 15, no. 7, p. 982-993. doi:10.1191/0959683605hl872ra.

Morard, S., Delaloye, R., and Dorthe, J., 2008, Seasonal thermal regime of a mid-latitude ventilated debris accumulation, in Kane, D.L., and Hinkel, K.M., eds., Ninth International Conference on Permafrost: Fairbanks, Institute of Northern Engineering, University of Alaska, v. 2, p. 1233-1238.

New Hampshire Natural Heritage Bureau, 2009, Ice Gulch—a trail maintained by the Randolph Mountain Club, one sheet brochure, https://www. nhdfl.org/library/pdf/Natural\%20Heritage/icegulch.pdf [accessed June 15, 2013].

Nield, D.A., and Bejan, A., 1992, Convection in Porous Media, second edition: New York, Springer-Verlag, 408 p.

Osterkamp, T.E., and Jorgenson, M.T., 2009, Permafrost conditions and processes, in Young, R., and Norby, L., eds., Geological Monitoring: Boulder, Colorado, Geological Society of America, p. 205-227. doi:10.1130/2009.monitoring(09).

Pflitsch, A., Meyer, C. and Holmgren, D., 2014, Mysterious Underworld - RUB researchers explore climate dynamics in caves: Rubin Science Magazine, International Edition 2014, p. 52-57.

Růžička, V., Zacharda, M., Němcová, L., Šmilauer, P., and Nekola, J.C., 2012, Periglacial microclimate in low-altitude scree slopes supports relict biodiversity: Journal of Natural History, v. 46, no. 35-36, p. 2145-2157. doi:10.1080/00222933.2012.707248.

Sawada, Y., Ishikawa, M., and Ono, Y., 2003, Thermal regime of sporadic permafrost in a block slope on Mt. Nishi-Nupukaushinupuri, Hokkaido Island, Northern Japan: Geomorphology, v. 52, p. 121-130. doi:10.1016/S0169-555X(02)00252-0.

Walegur, M.T., and Nelson, F.E., 2003, Permafrost distribution in the Appalachian Highlands, northeastern USA, in Phillips, M., Springman, S.M., and Arenson, L.U., eds., Proceedings of the Eighth International Conference on Permafrost, Lisse, The Netherlands, v. 2, p. $1201-1206$.

Whalley, W.B., and Azizi, F., 2003, Rock glaciers and protalus landforms: Analogous forms and ice sources on Earth and Mars: Journal of Geophysical Research, v. 108, no. E4, p. 8032-8048. doi:10.1029/2002JE001864.

Zacharda, M., Gude, M., and Růžička, V., 2007, Thermal regime of three low elevation scree slopes in Central Europe: Permafrost and Periglacial Processes, v. 18, p. 301-308. doi:0.1002/ppp.598. 